\title{
Epilithic diatoms in headwater areas of the hydrographical sub- basin of the Andreas Stream, RS, Brazil, and their relation with eutrophication processes
}

Diatomáceas epilíticas em áreas de nascentes da sub-bacia hidrográfica do Arroio Andreas, RS, Brasil, e sua relação com processos de eutrofização

Carla Giselda Heinrich, Valéria Louzada Leal, Marilia Schuch, Adriana Düpont and Eduardo Alcayaga Lobo

Limnology Laboratory, Department of Biology and Pharmacy, University of Santa Cruz do Sul - UNISC, Av. Independência, 2293, CEP 96815-900, Santa Cruz do Sul, RS, Brazil e-mail: carla.heinrich@hotmail.com; valeria.louzadaleal@gmail.com; marilias.sch@gmail.com; adrianad@unisc.br; lobo@unisc.br

\begin{abstract}
Aim: This research aimed to study the composition of epilithic diatom flora in headwater areas of the sub-basin of the Andreas stream, RS, Brazil, and their relation with eutrophication processes. Methods: Quarterly excursions (March, June, September, December 2012 and Mach 2013) were performed in ten sampling points selected in the sub-basin, to collect samples for the identification and counting the organisms in the group of diatoms (Class Bacillariophyceae). Results: The results indicated the occurrence of 243 taxa, distributed in 53 genera. Of these, 59 were considered abundant, being distributed in 29 genera. Seven species showed elevated tolerance levels to organic pollution and eutrophication: Adlafia drouetiana (R. M. Patrick) Metzeltin \& LangeBertalot, Amphipleura lindheimeri Grunow; Fallacia monoculata (Hustedt) D. G. Mann, Navicula cryptotenella Lange-Bertalot, Navicula symmetrica R. M. Patrick, Nitzschia palea (Kützing) W. Smith and Sellaphora auldreekie D. G. Mann \& S. M. McDonald in Mann et al. Conclusion: Although this research has been conducted in headwater areas, the occurrence of these seven species could be explained by considering the use of these areas for agricultural and livestock purposes, compromising the stability of these aquatic ecosystems, due to the significant contribution of fertilizer and organic matter, a condition that characterizes a process of eutrophication.
\end{abstract}

Keywords: headwater areas, water quality, diatoms, eutrophication, sub-basin of Andreas Stream, RS.

Resumo: Objetivo: A presente pesquisa objetivou o estudo da composição da flora de diatomáceas epilíticas em áreas de nascentes da Sub-bacia Hidrográfica do Arroio Andréas, RS, Brasil, e sua relação com processos de eutrofização. Métodos: Excursões trimestrais (Março, Junho, Setembro, Dezembro de 2012 e Março de 2013) foram realizadas em dez pontos de coleta selecionados na sub-bacia, para coletar amostras para a identificaçẫo e contagem dos organismos do grupo das diatomáceas (Classe Bacillariophyceae). Resultados: Os resultados indicaram a ocorrência de 243 táxons, distribuídos em 53 gêneros. Destes, 59 foram considerados abundantes, estando distribuídos em 29 gêneros. Sete espécies apresentaram níveis de tolerância elevados à poluição orgânica e eutrofização: Adlafia drouetiana (R. M. Patrick) Metzeltin \& LangeBertalot, Amphipleura lindheimeri Grunow; Fallacia monoculata (Hustedt) D. G. Mann, Navicula cryptotenella Lange-Bertalot, Navicula symmetrica R. M. Patrick, Nitzschia palea (Kützing) W. Smith and Sellaphora auldreekie D. G. Mann \& S. M. McDonald in Mann et al. Conclusáo: Embora a pesquisa tenha sida realizada em áreas de nascentes, a ocorrência destas sete espécies poderia ser explicada considerando o uso destas áreas para fins agrícolas e criação de animais, comprometendo a estabilidade destes ecossistemas aquáticos em função do aporte significativo de fertilizantes e matéria orgânica, condição que caracteriza um processo de eutrofização.

Palavras-chave: áreas de nascentes, qualidade da água, diatomáceas, eutrofização, sub-bacia do Arroio Andréas, RS. 


\section{Introduction}

Despite the extensive hydrographic network that characterizes Brazil, divided into eight major basins (Amazon, Tocantins River, North Atlantic and Northeast, San Francisco River, eastern Atlantic, Parana River, Uruguay River and Southeast Atlantic), there are few systems of monitoring water quality that have been implemented (Moresco and Rodrigues, 2013), considering that they are essential to increase understanding of the problems related to pollution of aquatic ecosystems (Bodo, 1992; Mohlenberg et al., 2007).

Concerning the methodologies for water quality evaluation, researchers worldwide (e. g., Cairns Junior and Pratt, 1993) argue that traditional techniques based on physical, chemical and bacteriological characteristics are not enough to meet their multiple uses, since they are particularly deficient in the evaluation of aesthetics, recreation and ecological environmental conditions, being necessary therefore an integrated quality analysis, considering not only the traditional valuation methodologies, but the biological aspects of the system.

Among the bioindicator organisms of the environmental conditions of lotic systems, the use of diatoms (Bacillariophyceae) has a long history (Stevenson and Pan, 1999). They are predominantly free-living unicellular microscopic organisms, sometimes filamentous organisms gathered in colonies, surrounded by a layer of mucilage (Joly, 1979). Currently, diatoms are represented by about 100,000 species distributed in 250 genera and have a wide geographical distribution, occurring along rivers, estuaries, lakes, marine environments and a variety of substrates, natural or artificial, being observed also in humid environment, ice and hot spring waters (Hoek et al., 1995).

These organisms are one of the main dominant groups of periphytic algae in lotic systems and also efficient indicators of environmental changes, since they respond sensitively to physical and chemical changes of water (Winter and Dunthie, 2000; Lobo et al., 2002), as well as to differences in geology, climate and land use between watersheds (Stoermer and Smol, 1999). Because they have a strongly silicified cell wall, these organisms can be easily mounted in permanent microscope slides, requiring no special treatment for preservation.

However, the need for a thorough understanding of the taxonomy of diatoms has been identified as one of the major problems for using this group of algae in biological monitoring programs
(Sabater et al., 1991). Although it is known that a high number of species are cosmopolitan (Kociolek and Spaulding, 2000), there is few information in the literature about the diatom flora in Latin America, a fact that significantly affect the correct identification of the species, since the base used is mainly the European bibliography (e. g., Krammer and Lange-Bertalot, 1986, 1988, 1991a, b; LangeBertalot, 1993). Round (1993) recommends extreme caution when identifying species found in the southern hemisphere based on studies of European flora, because, although apparently identical, the species often have subtle variations.

In this context, the present research aimed to study the composition of epilithic diatom flora in headwater areas of the sub-basin of the Andreas stream, RS, Brazil, and their relation with eutrophication processes.

\section{Material and Methods}

\subsection{Study area}

Located in the central region of Rio Grande do Sul state, the Andreas Stream Hydrographic Sub-basin is inserted in Vera Cruz city, one of the 13 municipalities that compose the Pardo River Hydrographic Basin (Figure 1). It shows a drainage area of $80.2 \mathrm{~km}^{2}$, containing an urban population of 11,183 inhabitants and a rural population of 2,964 inhabitants. Land use is characterized by agriculture, including the presence of irrigated rice.

\subsection{Data collection}

Quarterly excursions (March, June, September, December 2012 and Mach 2013) were performed at ten sampling stations selected in the Andreas Stream Hydrographic Sub-basin (Figure 1), to collect samples for the identification and counting the organisms in the group of diatoms (Class Bacillariophyceae). The selection of the class Bacillariophyceae followed the recommendations of Round (1991, 1993) and Sabater et al. (1991). For qualitative and quantitative analysis, diatom samples were scrubbed off the upper surface of three to five submerged stones, 10 to $20 \mathrm{~cm}$ in diameter, using a toothbrush, and were fixed with formalin following the method described by Kobayasi and Mayama (1982). The samples were cleaned with sulfuric and hydrochloric acids and mounted on permanent slides with Naphrax. To estimate the relative abundance of the species, all the organisms found in random transects under light microscopy through the prepared permanent slides were 


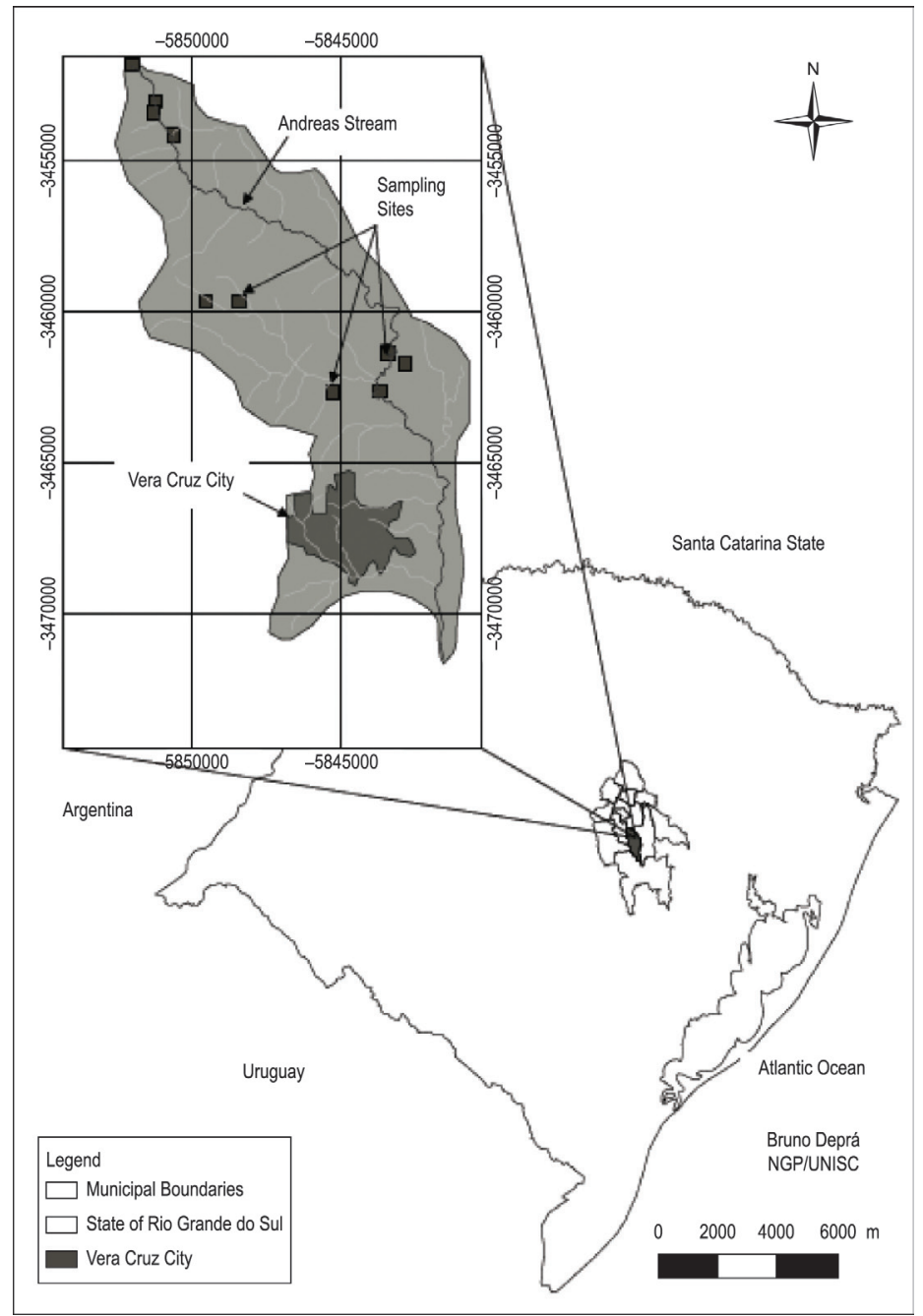

Figure 1. Map of the study area and localization of the Andreas Stream Sub-basin, in the municipality of Vera Cruz, RS, Brazil.

identified and counted up to a minimum of 600 valves using an Olympus BX-40 microscope. For the identification of species, the following taxonomic references were used: Bes et al. (2012), Metzeltin and Lange-Bertalot (1998, 2007), Rumrich et al. (2000), Metzeltin and García-Rodríguez (2003) and Metzeltin et al. (2005). Abundant species were determined according to Lobo and Leighton (1986). The permanent slides are stored in the DIAT-UNISC Herbarium at the University of Santa Cruz do Sul (RS), Brazil.

\section{Results and Discussion}

A total of 243 species were identified, belonging to 53 genera, 59 taxa were considered abundant, being distributed in 29 genera (Table 1). Regarding the genera level, Navicula Bory and Gomphonema Ehrenberg were the most representative, with eight and six species, respectively.
Among the abundant species, seven of them showed higher levels of tolerance to organic pollution and eutrophication (Figures 2 to 55), following the classification proposed by Lobo et al. (2004a). They are:

Adlafia drouetiana (R. M. Patrick) Metzeltin \& Lange-Bertalot (Figures 33 to 43)

This species is cited as tolerant to organic pollution and eutrophication in southern Brazilian rivers (Lobo et al. 2004a, 2010). to 4)

Amphipleura lindheimeri Grunow (Figures 2

Freshwater taxon (oligohalobous), characteristic of standing water, but may also occurs in running water (limnophilous) (Shirata, 1985). For southern Brazilian rivers, this species is cited as characteristic of $\alpha$-polysaprobic pollution environments (very heavily polluted) (Lobo et al., 2002) and highly tolerant to eutrophication (Lobo et al. 2004a, 2010). 
Fallacia monoculata (Hustedt) D. G. Mann (Figures 44 to 53)

Cosmopolitan species, extremely tolerant to eutrophication and organic pollution OuvirLer foneticamente (Van Dam et al., 1994; Souza and Senna, 2009; Lobo et al., 2004a, 2010; Schuch et al., 2012).
Navicula cryptotenella Lange-Bertalot (Figures 18 to 26)

Species found in freshwater (Lange-Bertalot, 2001) and brackish (Hodgson et al., 1997). Occurring in lentic waters as well as lotic waters (Lowe, 1974), and classified as epilithic, periphytic and planktonic (Tolonen, 1978; Torgan and

Table 1. List of the abundant diatom species in the Andreas Stream Sub-basin, RS, Brazil.

Achnanthes paraexigua Metzeltin \& Lange-Bertalot

Achnanthidium exiguum (Grunow) Czarnecki

Achnanthidium exiguum var. constrictum (Grunow) N. A. Andresen, Stoermer \& Kreis

Achnanthidium minutissimum (Kützing) Czarnecki

Adlafia drouetiana (R. Patrick) Metzeltin \& Lange-Bertalot

Adlafia muscora (Kociolek \& Reviers) Gerd Moser, Lange-Bertalot \& Metzeltin

Amphipleura lindheimeri Grunow

Brachysira neoxilis Lange-Bertalot

Caloneis hyalina Hustedt

Cocconeis lineata Ehrenberg

Cocconeis placentula var. acuta F. Meister

Diploneis subovalis Cleve

Eolimna minima (Grunow) Lange-Bertalot

Eolimna subminuscula (Manguin) Gerd Moser, Lange-Bertalot \& Metzeltin

Eunotia kruegeri Lange-Bertalot

Eunotia veneris (Kützing) A. Berg

Fallacia meridionalis Metzeltin, Lange-Bertalot \& García Rodríguez

Fallacia monoculata (Hustedt) D. G. Mann

Frustulia guayanensis ssp. ecuadoriana Lange-Bertalot \& Rumrich

Geissleria punctifera (Hustedt) Lange-Bertalot

Gomphonema angustatum (Kützing) Rabenhorst

Gomphonema bourbonense E. Reichardt

Gomphonema brasiliense Grunow

Gomphonema brasiliensoide Metzeltin, Lange-Bertalot \& García Rodríguez

Gomphonema lagenula Kützing

Gomphonema parvulum Kützing

Halamphora montana (Krasske) Levkov

Humidophila contenta (Grunow) Lowe et al.

Humidophila lacunosa (Gerd Moser, Lange-Bertalot \& Metzeltin) Lowe et al.

Humidophila subtropica (Metzeltin, Lange-Bertalot \& García-Rodríguez) Lowe et al.

Luticola simplex Metzeltin, Lange-Bertalot \& García-Rodríguez

Mayamaea agrestis (Hustedt) Lange-Bertalot

Mayamaea permitis (Hustedt) Bruder \& Medlin

Navicula capitatoradiata (Cleve) Germain

Navicula cruxmeridionalis Metzeltin, Lange-Bertalot \& García-Rodríguez

Navicula cryptotenella Lange-Bertalot

Navicula germainii J. H. Wallace

Navicula gregaria Donkin

Navicula lohmanii Lange-Bertalot \& Rumrich

Navicula symmetrica R. M. Patrick

Naviculadicta aff. cosmopolitana Lange-Bertalot in Rumrich et al.

Nitzschia amphibia Grunow

Nitzschia claussi Hantzsch

Nitzschia inconspicua Grunow

Nitzschia palea (Kützing) W. Smith

Nitzschia supralitorea Lange-Bertalot

Nupela pardinhoensis Bes, Torgan \& Ector in Bes et al.

Nupela praecipua (E. Reichardt) E. Reichardt

Nupela welnerii (Lange-Bertalot) Lange-Bertalot in Rumrich et al.

Placoneis humilis Metzeltin, Lange-Bertalot \& García-Rodríguez

Planothidium bagualense C. E. Wetzel \& Ector

Planothidium salvadorianum (Hustedt) Lange-Bertalot

Platessa hustedtii (Krasske) Lange-Bertalot

Pleurosira laevis (Ehrenberg) Compère

Sellaphora auldreekie D. G. Mann \& S. M. McDonald in Mann et al.

Sellaphora seminulum (Grunow) D. G. Mann

Simonsenia delognei (Grunow) Lange-Bertalot

Surirella bouillonii Bes, Ector \& Torgan in Bes et al.

Ulnaria ulna (Nitzsch) Compère 


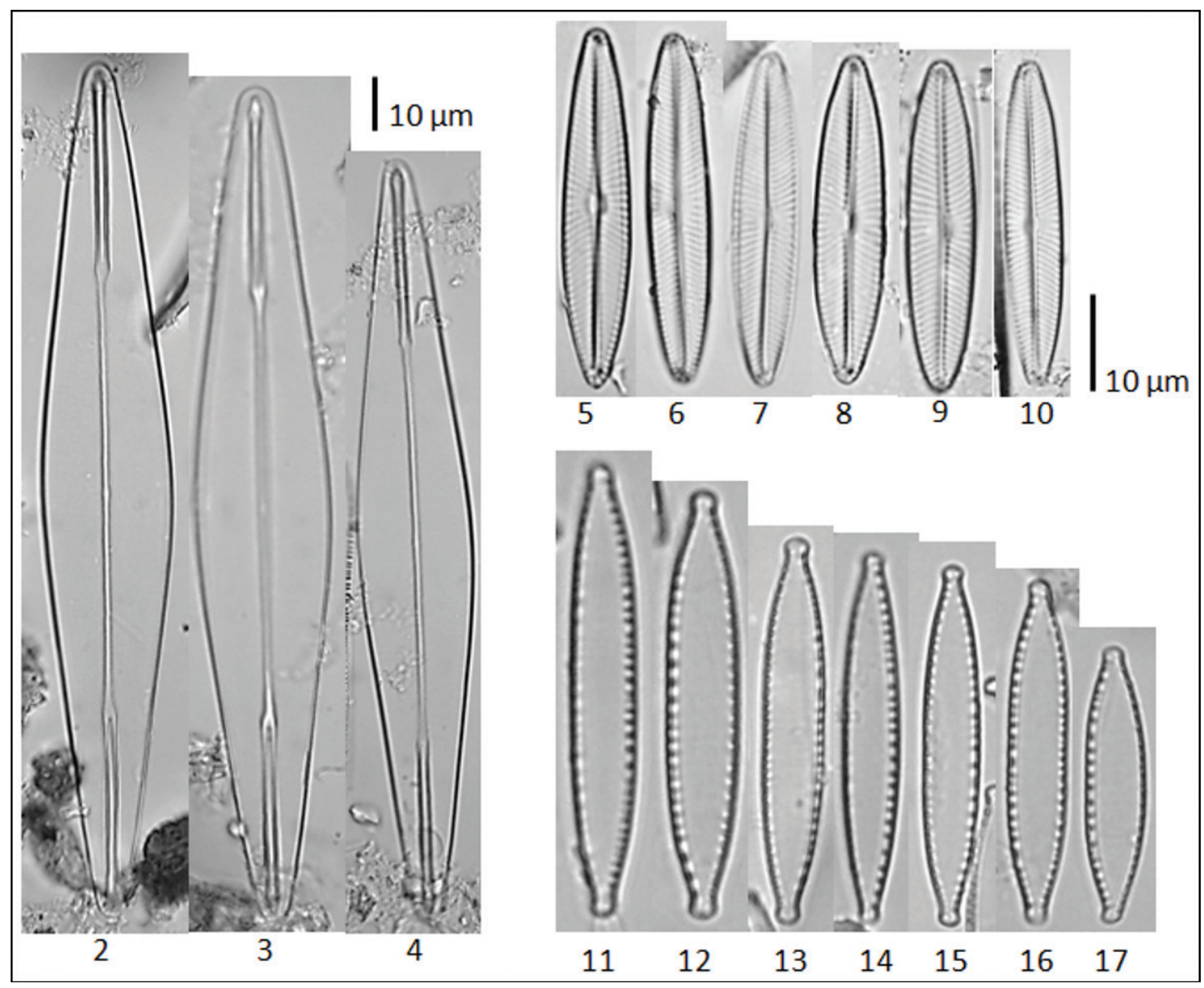

Figures 2-17. Abundant diatom species in the Andreas Stream Sub-basin, RS, Brazil. 2-4: Amphipleura lindheimeri; 5-10: Navicula symmetrica; 11-17: Nitzschia palea.

Biancanaro, 1991; Kuhn et al., 1981; Lowe, 1974). Characteristic of $\alpha$-polysaprobic environments (very heavily polluted) according to Lobo et al., (2002) and cited as tolerant to organic pollution and highly tolerant to eutrophication (Lobo et al., 2004a, 2010). Yet, Van Dam et al. (1994) pointed out that this species has a wide tolerance to trophy, from oligotraphentic to hypereutraphentic environments.

Navicula symmetrica R. M. Patrick (Figures 5 to 10 )

This species is characteristic of $\alpha$-polisaprobic environments in southern Brazilian rivers (Lobo et al., 2002), as well as tolerant to organic pollution and highly tolerant to eutrophication (Lobo et al. 2004a, 2010).

Nitzschia palea (Kützing) W. Smith (Figures 11 to 17 )

Cosmopolitan species, widely recognized as tolerant to organic pollution, according LangeBertalot (1979), Kobayasi and Mayama (1989) and Watanabe et al. (1988) as well as eutrophication
(Lobo et al. 2004a, 2010; Schuch et al., 2012). Moreover, Van Dam et al. (1994) and Silva et al. (2010) argued that $N$. palea is a polysaprobic species, indicative of hypereutraphentic conditions. Bruno et al. (2003) confirmed N. palea as an indicator of high nutrient loads and Krammer and Lange-Bertalot (1988) affirm that this species has a wide range of tolerance to organic contamination, from mesosaprobic to polysaprobic environments, with an ecological optimum in highly polluted waters.

Sellaphora auldreekie D. G. Mann \& S. M. McDonald in Mann et al. (Figures 27 to 32)

Cosmopolitan species, occurring in freshwater (Van Heurck, 1896) to slightly brackish (Hodgson et al., 1997). Abundant taxa in eutrophic environments with high phosphate concentrations (Lobo et al., 2004b). Still Schuch et al. (2012), studying urban streams in Santa Cruz do Sul, RS, Brazil, found the specie as highly abundant in eutrophic and organically polluted environments. 


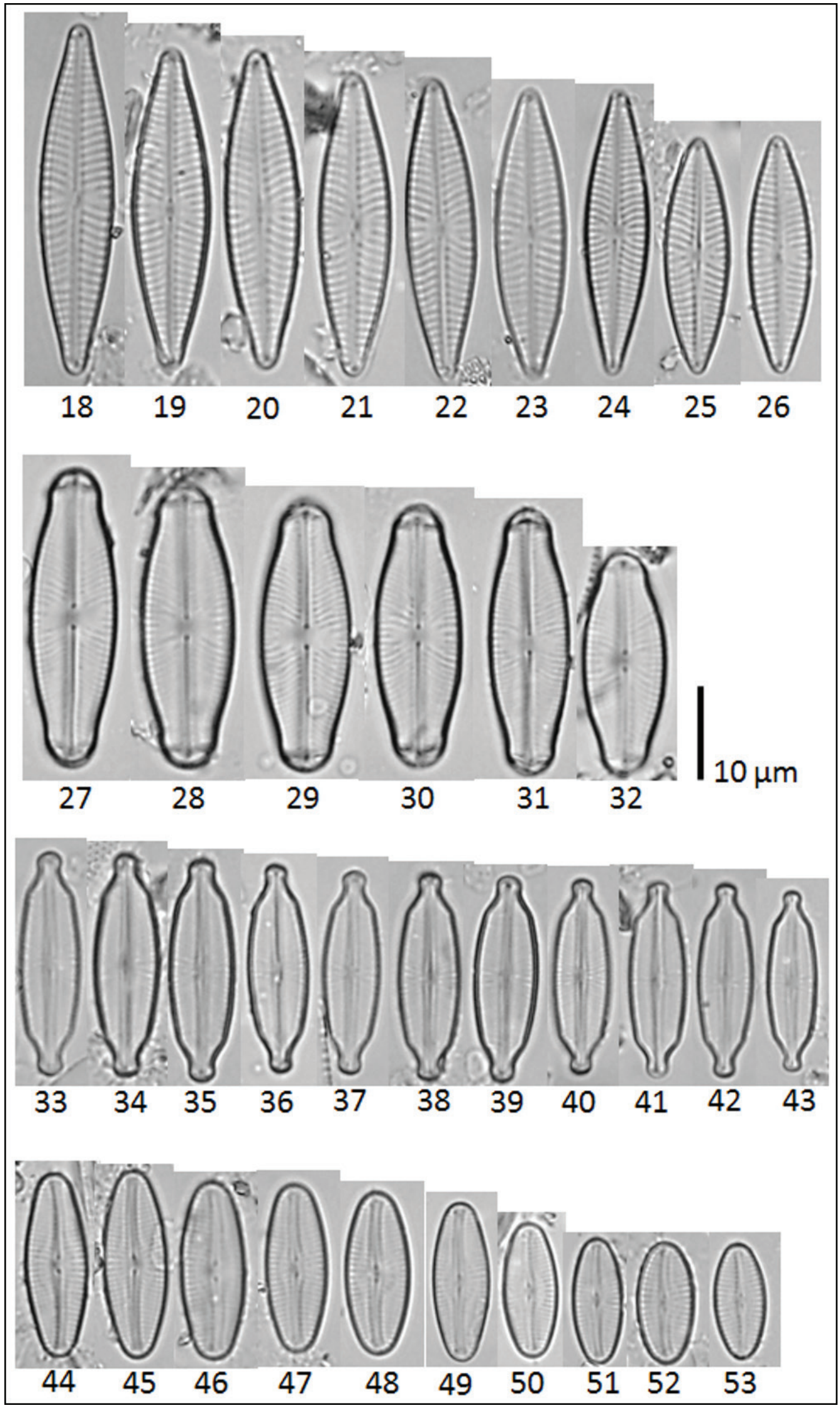

Figures 18-53. Abundant diatom species in the Andreas Stream Sub-basin, RS, Brazil. 18-26: Navicula cryptotenella; 27-32: Sellaphora auldreekie; 33-43: Adlafia drouetiana; 44-53: Fallacia monoculata. 


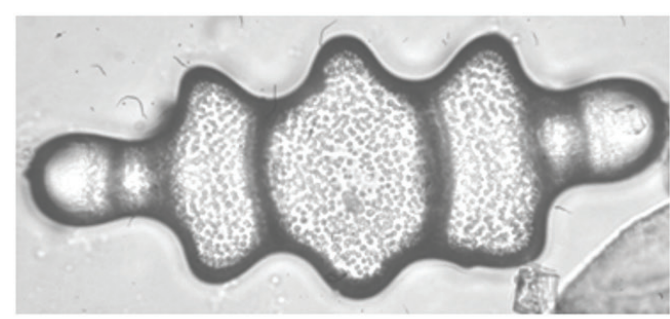

54

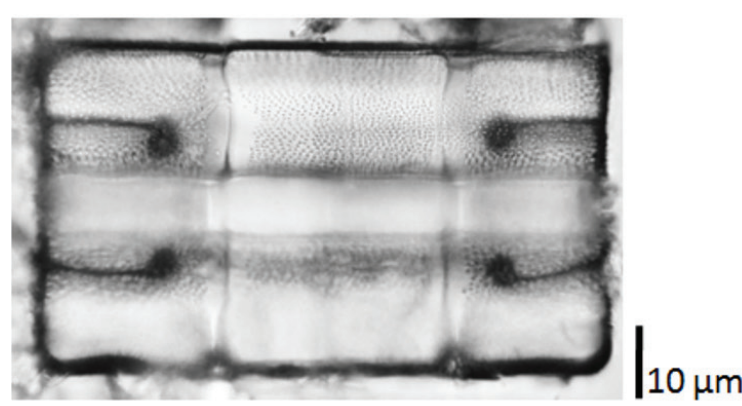

55

Figures 54-55. Terpsinoë musica, new citation to headwater areas at Rio Grande do Sul.

Finally, we emphasize the occurrence of a new citation to headwaters in the state of Rio Grande do Sul:

Terpsinoë musica Ehrenberg (Figures 54, 55)

Among the records of this taxon realized in Brazil, we highlight the researches developed by Brassac et al. (1999), Rosa et al. (1994) and Tremarin et al. (2009). According to Round et al. (1990), this species has a large ecological distribution and can be found in brackish and freshwaters; frequently in humid rocks of tropical regions. Some studies, for example Zalocar De Domitrovic and Maidana (1997), highlight the epiphytic or epilithic habit of this taxon as well as their preference for euryhaline environments. The study also records the occurrence of this species associated with specimens of Pleurosira laevis and Hydrosera whampoensis; this species association was also verified in this present research.

\section{Conclusion}

The results indicate the occurrence of 243 taxa, 59 of them considered abundant species, distributed in 29 genera, characterizing the flora of epilithic diatoms in headwater areas of the Andreas Stream Sub-basin, RS, in order to provide subsidies to the correct delimitation and identification of species used in the diagnosis and characterization of aquatic environments.

Although this research has been conducted in headwater areas, the flora composition revealed seven species with high levels of tolerance to organic pollution and eutrophication, which could be explained considering the use of these areas for agricultural and livestock purposes, compromising the stability of these aquatic ecosystems due to the significant contribution of fertilizer and organic matter, condition that characterizes a eutrophication process.

\section{Acknowledgements}

The authors want to thank the Brazilian Research Council (CNPq) and the University of Santa Cruz do Sul (UNISC), by the undergraduate scholarships granted to first and second author of this scientific article, PUIC/UNISC and PIBIC/ $\mathrm{CNPq}$, respectively. We also thank to Dr. Carlos Wetzel and Dr. Luc Ector, from the Institute Gabriel Lippmann in Luxembourg, for their assistance in the taxonomic nomenclature procedures. Yet, we thank the $\mathrm{CNPq}$ by financial support of this research (Edict MCT/CNPq/Universal - no 14/2011).

\section{References}

BES, D., ECTOR, L., TORGAN, LC. and LOBO, EA. 2012. Composition of the epilithic diatom flora from a subtropical river, Southern Brazil. Iheringia Série Botânica, vol. 67, no. 1, p. 93-125.

BODO, BA. 1992. Statistical analyses of regional surface water quality in southeastern Ontario. Environmental Monitoring and Assessment, vol. 23, no. 1-3, p. 165187. PMid:24227098.

BRASSAC, NM., ATAB, DR., LANDUCCI, M., VISINONI, ND. and LUDWIG, TAV. 1999. Diatomáceas cêntricas de rios da regiáo de abrangência da usina hidrelétrica de Salto Caxias, PR (Bacia do Iguaçu). Acta Botanica Brasilica, vol. 13, no. 3, p. 277-289.

BRUNO, E., MARTINEZ DE FABRICIUS, A. and LUQUE, ME. 2003. Fitoplancton en un tramo del Río Cuarto con influencia antrópica. Boletin de la Sociedad Argentina Botánica, vol. 38, no. 1-2, p. 1-13.

CAIRNS JUNIOR, J. and PRATT, JR. 1993. A history of biological monitoring using benthic macroinvertebrates. In ROSENBERG DM. and RESH VH., org. Freshwater biomonitoring and benthic macroinvertebrates. New York: Chapman \& Hall. 488 p.

HODGSON, D., VYVERMAN, W. and TYLER, P. 1997. Diatoms of meromictic lakes adjacent to the Gordon river, and of the Gordon river estuary in south- 
west Tasmania. Berlin: J. Cramer. 172 p. (Bibliotheca Diatomologica).

HOEK, CV, MANN, DG. and JAHNS, HM. 1995. Algae: an introduction to phycology. Cambridge: Cambridge University Press. 623 p.

JOLY, AB. 1979. Botânica: introdução à taxonomia vegetal. São Paulo: Companhia Editora Nacional. $777 \mathrm{p}$.

KOBAYASI, H. and MAYAMA, S. 1982. Most pollution tolerant diatoms of severely polluted rivers in the vicinity of Tokyo. Japanese Journal of Phycology, vol. 30, no. 3, p. 188-196.

KOBAYASI, H. and MAYAMA, S. 1989. Evaluation of river water quality by diatoms. The Korean Journal of Phycology, vol. 4, p. 121-133.

KOCIOLEK, JP. and SPAULDING, SA. 2000. Freshwater diatom biogeography. Nova Hedwigia, vol. 71, no. 1-2, p. 223-241.

KRAMMER, K. and LANGE-BERTALOT, H. 1986. Bacillariophyceae. 1. Teil: Naviculaceae. In ETTL, H., GERLOFF, J. HEYNIG, H. and MOLLENHAUER, D., org. Süßwasserflora von Mitteleuropa. Stuttgart: Gustav Fisher Verlag. 876 p. (vol. 2/1).

KRAMMER, K. and LANGE-BERTALOT, H. 1988. Bacillariophyceae. 2. Teil: Bacillariaceae, Epithemiaceae, Surirellaceae. In ETTL, H., GERLOFF, J., HEYNIG, H. and MOLLENHAUER, D., org. Süßwasserflora von Mitteleuropa. Stuttgart: Gustav Fischer Verlag. 610 p. (vol. 2/2).

KRAMMER, K. and LANGE-BERTALOT, H. 1991a. Bacillariophyceae. 3. Teil: Centrales, Fragilariaceae, Eunotiaceae. In ETTL, H., GERLOFF, J., HEYNIG, H. and MOLLENHAUER, D., org. Süsswasserflora von Mitteleuropa. Stuttgart: Gustav Fischer Verlag. 598 p. (vol. 2/3).

KRAMMER, K. and LANGE-BERTALOT, H. 1991b. Bacillariophyceae. 4. Teil: Achnantaceae. Kritische Ergänzungen zu Achnanthes, Navicula und Gomphonema. In ETTL, H., GÄRTNER, G., GERLOFF, J., HEYNIG, H. and MOLLENHAUER, D., org. Süsswasserflora von Mitteleuropa. Stuttgart: Gustav Fischer Verlag. 468 p. (vol. 2/4).

KUHN, DL., PLAFKIN, JL., CAIRNS, JR. and LOWE, RL. 1981. Qualitative characterization of aquatic environments using diatoms life-form strategies. Transactions of the American Microscopical Society, vol. 100, no. 2, p. 165-182. http://dx.doi. org $/ 10.2307 / 3225800$

LANGE-BERTALOT, H. 1979. Pollution tolerance of diatoms as a criterion for water quality estimation. Nova Hedwigia Beiheft, vol. 64, no. 1, p. 285-304.

LANGE-BERTALOT, H. 1993. 85 Neue Taxa und über 100 weitere neu definierte Taxa ergänzend zur Süßwasserflora von Mitteleuropa. Berlim: J. Cramer. 428 p. (Bibliotheca Diatomologica, vol. 2/1-4).
LANGE-BERTALOT, H. 2001. Navicula sensu stricto: 10 genera separated from Navicula sensu lato, Frustulia. In LANGE-BERTALOT, H., org. Diatoms of the Europe. Ruggell: A.R.G. Gantner Verlag Kommanditgesellschaft. 526 p.

LOBO, EA., CALLEGARO, VL., HERMANY, G., BES, D., WETZEL, CE. and OLIVEIRA, MA. $2004 \mathrm{a}$. Use of epilithic diatoms as bioindicator from lotic systems in southern Brazil, with special emphasis on eutrophication. Acta Limnologica Brasiliensia, vol. 16, no. 1, p. 25-40.

LOBO, EA., BES, D., TUDESQUE, L. and ECTOR, L. 2004b. Water quality assessment of the Pardinho River, RS, Brazil, using epilithic diatom assemblages and faecal coliforms as biological indicators. Vie et Milieu, vol. 53, no. 2-3, p. 115-126.

LOBO, EA., CALlEGARO, VL. and BENDER, P. 2002. Utilização de algas diatomáceas epilíticas como indicadoras da qualidade da água em rios e arroios da Regiāo Hidrográfica do Guaíba, RS, Brasil. Santa Cruz do Sul: EDUNISC. 126 p.

LOBO, EA. and LEIGHTON, G. 1986. Estructuras comunitarias de las fitocenosis planctónicas de los sistemas de desembocaduras de ríos y esteros de la Zona Central de Chile. Revista Biología Marina, vol. 22, no. 1, p. 1-29.

LOBO, EA., WETZEL, CE., ECTOR, L., KATOH. K., BLANCO, S. and MAYAMA, S. 2010. Response of epilithic diatom community to environmental gradients in subtropical temperate Brazilian rivers. Limnetica, vol. 29, no. 2, p. 323-340.

LOWE, RL. 1974. Environmental requirements and pollution tolerance of freshwater diatoms. Cincinnati: U.S. Environmental Protection Agency. 334 p.

METZELTIN, D. and GARCÍA-RODRÍGUEZ, F. 2003. Las Diatomeas Uruguayas. Montevideo: DIRAC/Facultad de Ciencias. 207 p.

METZELTIN, D. and LANGE-BERTALOT, H. 1998. Tropische Diatomeen in Südamerika I. 700 überwiegend wenig bekannte oder neue Taxa repräsentativ als Elemente der neotropischen Flora. Königstein: Koeltz Scientific Books. 695 p. (Iconographia Diatomologica).

METZELTIN, D. and LANGE-BERTALOT, H. 2007. Tropical Diatoms of South America II. Special remarks on biogeographic disjunction. Ruggell: A.R.G. Gantner Verlag Kommanditgesellschaft. 877 p. (Iconographia Diatomologica).

METZELTIN, D., LANGE-BERTALOT, H. and GARCÍA-RODRÍGUEZ, F. 2005. Diatoms of Uruguay: compared with other taxa from South America and elsewhere. Ruggell: A.R.G. Gantner Verlag Kommanditgesellschaft. 736 p. (Iconographia Diatomologica).

MOHLENBERG, F., PETERSEN, S., PETERSEN, AH. and GAMEIRO, C. 2007. Longterm trends and 
short-term variability of water quality in Skive Fjord, Denmark - nutrient load and mussels are the primary pressures and drives that influence water quality. Environmental Monitoring and Assessment, vol. 127, no. 1-3, p. 503-521. PMid:17058000. http://dx.doi. org/10.1007/s10661-006-9298-2

MORESCO, C. and RODRIGUES, L. 2013. O perifiton como bioindicador em rios. In SCHWARZBOLD, A., BURLIGA, AL. and TORGAN, LC., org. Ecologia do Perifiton. São Carlos: Rima. 155 p.

ROSA, Z., WERNER, VR. and DACROCE, L. 1994. Diatómaceas da lagoa de Tramandaí e da lagoa do Armazém, Rio Grande do Sul, Brasil: III- Ordem Centrales. Ihenringia, Série Botânica, vol. 45, p. 2955.

ROUND, FE. 1991. Diatoms in river water-monitoring studies. Journal of Applied Phycology, vol. 3, no. 2, p. 129-145. http://dx.doi.org/10.1007/BF00003695

ROUND, FE. 1993. A review and methods for the use of epilithic diatoms for detecting and monitoring changes in river water quality. London: HMSO Publisherp. 63 p.

ROUND, FE., CRAWFORD, RM. and MANN, DG. 1990. The diatoms: biology and morphology of the genera. Cambridge: Cambridge University Press. $747 \mathrm{p}$.

RUMRICH, U., LANGE-BERTALOT, H. and RUMRICH, M. 2000. Diatomeen der Anden. Von Venezuela bis Patagonien/Feuerlan. Ruggell: A.R.G. Gantner Verlag Kommanditgesellschaft. 649 p. (Iconographia Diatomologica).

SABATER, S., ARMENGOL, J., MARTI, E., SABATER, F. AND GUASCH, H. 1991. Benthic diatom communities as descriptors of discontinuities in the River Ter, Spain. In WHITTON, BA., ROTT, E. and FRIEDRICH, G., org. Use of algae for monitoring rivers. Innsbruck: Studia StudentenförderungsGes.m.b.H. p. 157-163.

SCHUCH, M., ABREU JÚNIOR, EF. and LOBO, EA. 2012. Water quality of urban streams, Santa Cruz do Sul, RS, Brazil, based on physical, chemical and biological analyses. Bioikos, vol. 26, no. 1, p. 3-12.

SHIRATA, MT. 1985. Catálogo de Diatomáceas (Chrysophyta, Bacillariophyceae) de água doce do estado do Paraná, Brasil. Curitiba: Estudos de Biologia. 64 p.

SILVA, AM., LUDWIG, TAV., TREMARIN, PI. and VERCELLINO, IS. 2010. Diatomáceas perifíticas em um sistema eutrófico brasileiro (Reservatório do Iraí, estado do Paraná). Acta Botanica Brasilica. vol. 24, no. 4, p. 997-1016. http://dx.doi.org/10.1590/ S0102-33062010000400015

SOUZA, MG. and SENNA, PA. 2009. Diatomáceas epilíticas da subordem Sellaphorineae do rio do
Monjolinho, São Carlos, SP, Brasil. Acta Botanica Brasilica, vol. 23, no. 3, p. 618-629. http://dx.doi. org/10.1590/S0102-33062009000300002

STEVENSON, RJ. and PAN, Y. 1999. Assessing environmental conditions in rivers and streams with diatoms. In STOERMER, EF. and SMOL, JP, org. The diatoms: applications for the environmental and earth science. Cambridge: Cambridge University Press. p. 11-40.

STOERMER, EF. and SMOL, JP. 1999. The diatoms: applications for the environmental and earth science. Cambridge: Cambridge University Press. 496 p.

TOLONEN, M. 1978. Palaeoecology of annually laminated sediments in Lake Ahvenainen, Finland. III. Human Influence in the lake development. Annales Botanici Fennici, vol. 15, no. 3, p. 223-240.

TORGAN, LC. and BIANCAMANO, MI. 1991. Catálogo das diatomáceas (Bacillariophyceae) referidas para o Estado do Rio Grande do Sul, Brasil, no periodo de 1973 a 1990. Santa Cruz do Sul: Faculdades Integradas de Santa Cruz do Sul. 196 p. (Caderno de Pesquisa. Série Botânica).

TREMARIN, PI., FREIRE, EG., BERTOLLI, LM. and LUDWIG, TAV. 2009. Catálogo das diatomáceas (Ochrophyta-Diatomeae) continentais do estado do Paraná. Iheringia, Série Botânica, vol. 64, no. 2, p. $79-107$.

VAN DAM, H., MERTENS, A. and SINKELDAM, J. 1994. A coded checklist and ecological indicator values of freshwater diatoms from The Netherlands. Netherlands Journal of Aquatic Ecology, vol. 28, no. 1, p. 117-133. http://dx.doi.org/10.1007/BF02334251

VAN HEURCK, H. 1896. A treatise on the diatomaceae. London: Willian Wesley \& Son. 558 p.

ZALOCAR DE DOMITROVIC, Y. and MAIDANA NI. 1997. Taxonomic and ecological studies of the Paraná River diatom flora (Argentina). Berlin: J. Cramer. 122 p. (Bibliotheca Diatomologica).

WATANABE, T., ASAI, K. and HOUKI, A. 1988. Numerical water quality monitoring of organic pollution using diatom assemblages. In ROUND, FE., org. Proceedings of the Ninth International Diatom Symposium, 1986. Koenigstein: Koeltz Scientific Books. p. 123-141.

WINTER, JG. and DUTHIE, HC. 2000. Epilithic diatoms as indicators of stream total $\mathrm{N}$ and total P concentrations. Journal of the North American Benthological Society, vol. 19, no. 1, p. 32-49. http:// dx.doi.org/10.2307/1468280

Received: 20 January 2014 Accepted: 19 September 2014 